\title{
Criminal Penalties FOR CONTRAVENTIONS OF PART IV OF THE TRADE PRACTICES ACT
}

\author{
JuLIE Clarke*
}

[In 2003 the Dawson Committee, commissioned by the Government, recommended that criminal penalties should be introduced for cartel conduct. The Government accepted this recommendation in principle and set up a working party to consider the implementation difficulties that had been identified in the Dawson Report. Nothing further was heard from the Government until February 2005 when the Government announced that it would introduce criminal penalties for serious cartel conduct. This paper evaluates the Government proposals and makes suggestions for their implementation.]

\section{INTRODUCTION}

Following a significant push, particularly by the Australian Competition and Consumer Commission (the ACCC), ${ }^{1}$ to introduce criminal penalties for serious breaches of the anti-competitive provisions of the TPA, the Government has re-

\footnotetext{
${ }^{*}$ Lecturer, School of Law, Deakin University.

${ }^{1}$ See, e.g., Press Release, ACCC, ACCC calls for stronger criminal sanctions including jail sentences for price-fixing offences under Trade Practices Act, (June 8, 2001), available at <http://www.accc.gov.au/content/index.phtml/itemId/87750/fromItemId/378012 and Professor Allan Fels, The Trades Practices Act and world's best practice: Proposals for criminal penalties for hard core collusion, Speech to the Australian Institute of Criminology (Sept. 2, 2002), available at http://www.accc.gov.au/content/index.phtml/itemId/110787/fromItemId/8973.
} 
cently announced it will introduce such penalties, including jail terms, for serious cartel conduct. $^{2}$

This announcement should be welcomed. Criminal penalties are appropriate for this type of conduct which costs the worldwide economy many billions of dollars each year. ${ }^{3}$ The new penalties will, combined with other announced reforms, provide a serious deterrent to individuals and corporations who might otherwise consider engaging in cartel conduct.

This paper will outline and critique the Government's proposals for criminal sanctions for certain forms of anti-competitive conduct and will make recommendations for the implementation of those proposals. First, however, the existing civil regime will be outlined followed by a discussion of the Dawson Report and related calls for criminalisation that have led to the current proposals. The threshold issue of whether criminal sanctions should be available for cartel conduct will also be addressed.

\section{Existing Regime for CARTel Conduct}

'Cartel' encompasses any form of conduct between competitors designed to limit the amount of competition in the markets in which they operate. The most common and pernicious forms of cartel conduct involve price fixing, bid rigging, output restrictions and market sharing arrangements between competitors. These forms of conduct are all prohibited, directly or indirectly, by Part IV of the Trade Practices Act 1974 (Cth) ('TPA'). Most of the more common forms of cartel conduct are currently prohibited per se, without need to prove anti-competitive consequences, through a combination of $s 45$ of the TPA and either s $4 \mathrm{D}^{4}$ or $45 \mathrm{~A} .^{5}$ Conduct not caught by the per se prohibition will still be caught by $\mathrm{s} 45$ if it can be demonstrated that competition has been, or is likely to be, substantially lessened.

\footnotetext{
2 Press Release, Australian Treasurer, Criminal Penalties for Serious Cartel Behaviour (Feb. 2 2005), available at <http://www.treasurer.gov.au/tsr/content/pressreleases/2005/004.asp>. These penalties will be introduced in the form of the Trade Practices Amendment (Cartel Conduct) Bill 2005: Press Release, Australian Treasurer and Australian Minister for Small Business and Tourism, Government Progressing Trade Practices Act Reforms (Mar. 10 2005), available at <http://www.treasurer.gov.au/tsr/content/pressreleases/2005/013.asp>.

3 See, e.g., OECD, HARD CORE CARTELS 5 (OECD 2000) (referring to 'cartels' multi-billion dollar drain on the global economy') and OECD, REPORT ON THE NATURE AND IMPACT OF HARD CORE CARTEls AND SANCTIONS AGAINST CARTELS UNDER NATIONAL COMPETITION LAWS 2 (OECD 2002) (noting that while difficult to quantify accurately, a conservative estimate of the worldwide economic harm from cartels is that 'it exceeds many billions of U.S. dollars per year).

4 This section defines exclusionary provisions (more commonly referred to as boycotts) which are prohibited by s 45 . The definition goes beyond traditional boycott scenarios and may capture some forms of cartel conduct.

5 This section deems price fixing to substantially lessen competition for the purposes of s 45 , thus rendering price fixing, which is likely to also incorporate most forms of output restrictions and market sharing, a per se offence under the TPA.
} 
Where a contravention of any of these prohibitions is proved, the TPA currently provides for a system of civil remedies, including pecuniary penalties, to be imposed by the Federal Court, with no opportunity for criminal punishment, either in the form of fines or incarceration. ${ }^{6}$ Currently penalties of up to $\$ 10 \mathrm{~m}$ are available for corporations and up to $\$ 500,000$ for individuals. ${ }^{7}$ This figure is, however, likely to increase in the near future as a result of the Trade Practices Legislation Amendment Bill (No. 1) 2005 ('Amendment Bill') which was introduced into Parliament on 17 February $2005 .^{8}$ This bill, if passed as expected, ${ }^{9}$ will significantly increase the maximum penalties for corporations to the higher of $\$ 10 \mathrm{~m}$ or 3 times the benefit gained from the contravention or, if that cannot be determined, $10 \%$ of the annual turnover of the corporation. ${ }^{10}$ There is no proposed change to the maximum pecuniary penalty for individuals.

In addition to these pecuniary penalties, the ACCC can seek other remedies for contraventions of Part IV, including declarations that the conduct was unlawful, injunctions banning repeat conduct or requiring the person involved to undertake compliance training or put in place compliance systems within the company, damages for those who have suffered loss and other orders, such as adverse publicity orders. ${ }^{11}$ If the Amendment Bill is passed it will also give the Court the power to make an order disqualifying an individual found to have contravened Part IV of the $T P A$ from acting in the management of a company ${ }^{12}$ and will prevent a corporation indemnifying an individual in respect of pecuniary penalties incurred as a result of a proved contravention of Part IV. ${ }^{13}$ Further, private action may be brought by parties who can demonstrate loss as a result of the cartel.

A leniency policy for cartel conduct also exists ${ }^{14}$ for the purpose of assisting detection and prosecution. This policy enables a cartel participant - corporate or indi-

\footnotetext{
6 Trade Practices Act, 1974, § 78 (Cth) ('[c]riminal proceedings do not lie against a person by reason only that the person: (a) has contravened ... a provision of Part IV ...').

7 Trade Practices Act, 1974, § 76(1) (Cth). Despite the size of the penalties available, in practice courts have been reluctant to apply penalties approaching the maximum available: see David Round, An empirical analysis of price-fixing penalties in Australia from 1974 to 1999: Have Australia's corporate colluders been corralled?, 8 COMPETITION C.L.J. 83, 95 (2000): 'judges have been reluctant to raise penalties by anywhere near an amount commensurate with the new maximum.' See also Energex, Submission to the Committee of Inquiry Into the Competition Law Provisions of the Trade Practices Act 1974, and Their Administration, Public Submission 46, Trade Practices Act Review, 6 (2002).

${ }^{8}$ This bill replaces the Trade Practices Legislation Amendment Bill 2004 (Cth) which lapsed on 31 August 2004 as a result of the October 2004 federal election.

9 The Government's majority in both the House of Representatives and the Senate from 1 July 2005 means the bill is likely to face few if any obstacles in passing through Parliament.

${ }_{10}$ The changes will occur via a new sub-section 76(1A): Trade Practices Legislation Amendment Bill (No. 1) 2005, schedule $9, \S 4$.

${ }^{11}$ See further Jennifer McNeill, Understanding prohibited cartel behaviour in order to minimise the risk of prosecution, Speech delivered at the Lexis Nexis Trade Practices Conference, Sydney (Sept. 9, 2004), available at http://www.accc.gov.au/content/index.phtml/itemId/536495/fromItemId/8973.

12 See Trade Practices Legislation Amendment Bill (No. 1) 2005, schedule 9, part 2.

13 See Trade Practices Legislation Amendment Bill (No. 1) 2005, schedule 9, part 3.

${ }^{14}$ ACCC, ACCC LENIENCY POLICY FOR CARTEL CONDUCT (2003) available at

http://www.accc.gov.au/content/index.phtml/itemId/454181. This policy came into effect at 9 am on 30 June 2003: see Press Release, ACCC, ACCC launches leniency policy to expose hard core cartels in
} 
vidual - to confess to the ACCC and, provided they are the first to come clean and the ACCC is not already aware of the cartel, they will receive amnesty from legal challenge by the ACCC. ${ }^{15}$ This policy has proved an effective mechanism in helping to detect and prosecute cartel conduct, with half the current 25 cartel investigations arising from business admissions. ${ }^{16}$

Finally, the current system of cartel regulation provides for certain exemptions, such as certain joint venture activities and the exercise of certain intellectual property rights ${ }^{17}$ and all forms of cartel conduct may be 'authorised' by the ACCC where it can be demonstrated the public benefit of the conduct 'outweighs or would outweigh the detriment to the public' in the form of reduced competition ${ }^{18}$ or, in the case of exclusionary provisions, would result in such benefit to the public that it should be allowed to be made. ${ }^{19}$

\section{Calls for Criminalisation and the Dawson COMMITTEE'S RECOMMENDATIONS}

\section{A Calls for criminalisation of cartel conduct}

On 9 June 2001 Professor Allan Fels, then Chairman of the ACCC, called for the introduction of criminal sanctions, including imprisonment, for 'hard core breaches of Part IV' including 'the most serious, flagrant and profitable acts of collusion such as price fixing, market sharing and bid rigging'. ${ }^{20}$

The ACCC's submission to the 2002 Trade Practices Inquiry, chaired by Sir Daryl Dawson (The Dawson Review) ${ }^{21}$ formalised their call for criminal penalties. Spe-

Australia ACCC launches leniency policy to expose hard core cartels in Australia, (June 27, 2003), available at http://www.acc.gov.au/content/index.phtml/itemId/346231/fromItemId/378016.

${ }^{15}$ There are certain other criteria that must be met to ensure immunity, set out in ACCC, ACCC LENIENCY POLICY, supra note 14. Note that the immunity only applies to ACCC-initiated proceedings so that corporations or individuals who satisfy the policy might still be subject to private actions. Importantly, however, private applicants do not have the power to bring an action for a pecuniary penalty.

${ }^{16}$ ACCC puts heat on 25 potential cartels (Feb. 17, 2005) available at $\mathrm{ABC}$ online http://www.abc.net.au/news/newsitems/200502/s1305026.html.

${ }^{17}$ For joint venture exemptions see Trade Practices Act, 1974, § 45A(2) (Cth) and for intellectual property exemptions see Trade Practices Act, 1974, § 51 (Cth).

18 Trade Practices Act, 1974, $\$ \$ 88(1), 90(7)$ (Cth).

19 Trade Practices Act, 1974, § 90(8) (Cth).

20 Allan Fels, Regulating in a High-Tech Marketplace, paper presented at the Penalties: Policy, Principles and Practice in Government Regulation Conference, Sydney (June 9, 2001), available at http://www.acc.gov.au/content/index.phtml/itemId/255481/fromItemId/8973. See also Press Release, ACCC, ACCC Calls for Stronger Criminal Sanctions, supra note 1. Note that the introduction of criminal penalties had also previously been considered by the Australian Law Reform Commission. See e.g. Stephen Corones, Penalties for price-fixing: a built-in feature of how we do business in Australia?, 24 Australian B. L. ReV. 160, 163 (1996).

${ }^{21}$ The Trade Practices Act Review was announced on 15 October 2001. Information about the Review, including all non-confidential public submissions is available from its web site, 
cifically, the ACCC proposed the introduction of criminal penalties for corporations and executives found to have engaged in hard-core cartel conduct ${ }^{22}$ to operate in conjunction with the existing civil penalty regime. ${ }^{23}$ Broadly, this would prohibit agreements to fix prices, limit output, share markets and rig bids. ${ }^{24}$ Upon conviction, it was proposed that a maximum custodial sentence of 7 years ${ }^{25}$ should apply for individuals and, for corporations, a fine 'at the same maximum level that would apply if the contravention were civil' should be imposed. ${ }^{26}$

The ACCC also originally proposed certain legislative 'safeguards' to ensure criminal sanctions would not be applied 'inappropriately'. ${ }^{27}$ These safeguards would include applying the criminal sanctions only to conduct carried out 'by, or in, large corporations, $^{28}$ - so as to exclude small business, trade unions and farmers ${ }^{29}$ - and ensuring that the offences be tried by a judge and jury with a requirement that the jury verdict be unanimous before a conviction is made. ${ }^{30}$ While the second of these recommendations sparked little comment, the proposal to restrict criminal sanctions to large corporations evoked considerable criticism and the ACCC subsequently proposed that 'the criminalisation of hard-core cartel behaviour for all, and not just large, corporations'. 31

\section{B The Dawson Committee's recommendations}

The Dawson Committee reported to the Treasurer in January 2003 and the report was released to the public on 16 April 2003. The Committee recommended the

http://tpareview.treasury.gov.au.

${ }^{22}$ ACCC, Submission to the Trade Practices Act Review, Public Submission 50, Trade Practices Act Review, 35 (2002).

${ }^{23}$ This proposal has prompted significant debate. A majority of the 212 submissions to the Dawson Review addressed the issue of criminal penalties for hard-core cartels, with opinions sharply divided.

${ }^{24}$ ACCC, Submission to the Trade Practices Act Review, supra note 22, at 35. Specifically, the ACCC has proposed that

... in addition [to] the existing civil offences, new criminal offences be created to criminalise agreements (contracts, arrangements or understandings) between competitors that would directly or indirectly: fix a price of a product or service; limit or prevent supply or production of a product or service; restrict the ability of the parties to the agreement to freely supply specified goods or services or to freely supply goods or services to specified customers; in response to a request for tenders, restrict the freedom of one or more of the parties to the agreement to put in independent tenders'.

25 ACCC, Submission to the Trade Practices Act Review, supra note 22, at 54.

${ }^{26} I d$. at 54. In this respect the ACCC also proposed increasing the level of civil penalties: Id. at 54-58.

27 Id. at 21.

${ }^{28}$ This aspect of the ACCC's proposal was heavily criticised, even by many who support the introduction of criminal sanctions. See, e.g., Australian Business Limited, Submission to the Review of the Trade Practices Act 1974, Public Submission 112, Trade Practices Act Review, 3 (2002) and Telstra Corporation Ltd, Initial Submission by Telstra Corporation Limited to the Dawson Committee Review of the Trade Practices Act, Public Submission 117, Trade Practices Act Review, 109-110 (2002.

${ }^{29}$ ACCC, Submission to the Trade Practices Act Review, supra note 22, at 41.

${ }^{30}$ Id. at 21, 43-49.

${ }^{31}$ SiR DARYl DAWSON, Jillian SEgAl AND CURT RENDALl, REVIEW OF THE COMPETITION PROVISIONS of THE TRADE PRACTICES ACT, 149 (Commonwealth of Australia, January 2003) ('Dawson Report') available at http://tpareview.treasury.gov.au/content/report.asp. 
introduction of criminal penalties, including imprisonment, for serious cartel behaviour, ${ }^{32}$ subject to solutions being found to certain problems they had identified. No endeavour was made to define 'serious cartel conduct', although the Committee did observe that there were 'undeniable difficulties in defining a criminal offence which covers only serious cartel behaviour.' 33

In addition to recommending the introduction of criminal penalties, the Dawson Committee recommended amendments to the civil penalty regime for Part IV of the TPA, encompassing cartel conduct. In particular, it recommended that the maximum pecuniary penalty for corporations be significantly increased, ${ }^{34}$ that the Court be given the power to exclude an individual involved in a contravention from being 'a director of a corporation or being involved in its management ${ }^{, 35}$ and that corporations be prohibited from indemnifying its 'officers, employees or agents' for pecuniary penalties they might receive. ${ }^{36}$

\section{Government Response to the Dawson Report}

The Commonwealth Government accepted 'in principle' that criminal penalties may provide a more effective deterrent than civil penalties, ${ }^{37}$ and subsequently set up a working party comprising officials from Treasury, the ACCC, the AttorneyGeneral's office and the Commonwealth Department of Public Prosecutions $(\mathrm{DPP})^{38}$ ('Working Party') to identify and resolve the implementation problems that had been identified in the Dawson Report.

Despite the expectation that the Working Party would report to the Treasurer by the end of $2003,{ }^{39}$ little or nothing more was heard from the Government on this issue until 2 February 2005 when it announced its intent to introduce criminal sanctions. The Working Party's report to the Treasurer has not been released, nor have any formal documents containing specifics of any proposed legislative amendments or guidelines, and they are unlikely to be in the near future as the Government consults with the States prior to the introduction of legislation.

\footnotetext{
${ }^{32} I d$. at 164 , rec 10.1 . This recommendation was made on the priviso that identified problems, including developing a 'satisfactory definition of serious cartel behaviour' first be resolved.

${ }^{33} I d$. at 155 . The key problems identified by the Committee were that 'a satisfactory definition of serious cartel behaviour needs to be developed and there needs to be a workable method of combining a clear and certain leniency policy with a criminal regime' (161-162).

${ }^{34} I d$. at 164 , rec 10.2.1. It was recommended that the penalties 'be raised to be the greater of $\$ 10$ million or three times the gain from the contravention or, where gain cannot be readily ascertained, 10 per cent of the turnover of the body corporate and all of its interconnected bodies corporate'.

35 Id. at 165 , rec 10.2 .2 .

${ }^{36}$ Id. at 165 , rec 10.2 .3

${ }^{37}$ Commonwealth of Australia, Commonwealth Government Response to the Review of the Competition Provisions of the Trade Practices Act 1974, 10 (April 2003) available at http://www.treasurer.gov.au/tsr/content/publications/TPAResponse.asp.

${ }^{38}$ See Press Release, Australian Treasurer, Working Party to Examine Criminal Sanctions for Cartel Behaviour (Oct. 3, 2003) available at

<http://www.treasurer.gov.au/tsr/content/pressreleases/2003/086.asp>.

${ }^{39}$ Id.
} 
Regardless of form, it is anticipated that the new laws criminalising certain cartel conduct will be in place by the end of the year. ${ }^{40}$ It is likely that the Trade Practices Amendment (Cartel Conduct) Bill 2005 will be introduced in the first half of the year and should have no difficulty passing through Parliament once the Government holds the balance of power in the Senate, as it will from 1 July 2005. In any case, the opposition has indicated that they will support the new laws, considering them to be long overdue. ${ }^{41}$

The Government also accepted all of the Dawson Committee's recommendations on civil remedies for cartel conduct ${ }^{42}$ and in 2004, introduced the Trade Practices Legislation Amendment Bill 2004 that was to give effect to those recommendations. That bill subsequently lapsed as a result of the 2004 federal election. ${ }^{43}$ However, it was recently reintroduced in substantially the same form. ${ }^{44}$ Consequently, it is anticipated civil penalties will increase for corporations and the power to exclude individuals from company management and to preclude corporations from indemnifying individuals will form part of the TPA by May this year.

\section{Should Criminal Penalties be Avallable for Cartel CONDUCt?}

Before embarking on an analysis of the Government's proposals, it is appropriate to first address the threshold question of whether criminal penalties should be available for cartel conduct. The key justifications advanced for the introduction of criminal penalties for cartel conduct are that

- they would provide a valuable and more effective deterrent to engaging in the conduct than the civil remedies currently available;

\footnotetext{
${ }^{40}$ Michael Rowland, Business Council wary of new laws cracking down on cartel activity (Feb. 2, 2005) available at $\mathrm{ABC}$ online - PM: 〈http://www.abc.net.au/pm/content/2005/s1294604.htm〉. Note, while the government has not publicly indicated a timeframe this appears a reasonable estimate. By contrast Leora Moldofsky has claimed the 'government plans to introduce the proposed laws into parliament by the end of March', which is too soon given the necessary consultation process: Australian regulator gets tougher on price fixing (Feb. 2 2005) accessed at FT.com. Consultation with the states commenced on 2 February 2005. The legislation will be introduced via the Trade Practices Amendment (Cartel Conduct) Bill 2005. This bill was still being drafted in March 2005. At the conclusion of drafting approval from the states is required over a 35 day voting period: see, Treasurer and Minister for Small Business and Tourism, supra note 2.

${ }^{41}$ Doorstop Interview with Wayne Swan MP, Shadow Treasurer, Australia, Labor welcomes these long overdue proposals from the Treasurer to curb cartel behaviour at Treasury Place, Melbourne (Feb. 2 2005). See also, Rowland, supra note 40.

${ }^{42}$ Commonwealth of Australia, Response to the Review of the Competition Provisions of the Trade Practices Act 1974, supra note 37, at 10 ..

${ }^{43}$ The bill lapsed on 31 August 2004 after it had passed through the House of Representatives without amendment and had been introduced and had its second reading in the Senate, on 5 August 2004.

${ }^{44}$ See supra note 8.
} 
- their introduction would ensure fairness and consistency with other forms of economic crime, such as insider trading, tax evasion and more common forms of theft; and

- $\quad$ it would be consistent with developing international best practice. ${ }^{45}$

A

\section{Deterrence}

The key justification advanced by the ACCC in calling for criminal sanctions, the Dawson Committee in recommending their introduction and by the Government in their proposal to introduce them, is that criminal penalties will provide a more effective deterrent than the existing civil penalties. ${ }^{46}$ In this respect the OECD has also suggested that the 'principal purpose of sanctions in cartel cases is deterrence' and that 'sanctions against individuals can provide important, additional deterrence'. 47

The two recognised forms of deterrence in criminal jurisprudence are specific deterrence and general deterrence. The former is punitive in nature and seeks to discourage crime in an endeavour to convince offenders not to re-offend. ${ }^{48}$ General deterrence, on the other hand, seeks to dissuade potential offenders by making clear there will be severe consequences if caught offending. It is general deterrence that provides the chief argument for criminalising cartel conduct; that is, criminal penalties will provide a more effective deterrent than civil penalties for first time offenders. While evidence suggests that in most cases the seriousness of the penalty does little to increase deterrence, ${ }^{49}$ white collar crime appears to be an exception to this rule. That is, to the extent that a correlation between severity of punishment and the

\footnotetext{
${ }^{45}$ See further Julie Clarke and Mirko Bagaric, The Desirability of Criminal Penalties for Breaches of Part IV of the Trade Practices Act, 31 Australian B. L. REV. 192-209 (2003).

${ }^{46}$ ACCC, Submission to the Trade Practices Act Review, supra note 22, at 35. See also Dawson Report, supra note 31 , at 153,163 . Deterrence also seems to be at the heart of the current civil regime: 'The principal, and I think probably the only, object of the penalties imposed by s 76 is to put a price on contravention that is sufficiently high to deter repetition by the contravener and by others who might be tempted to contravene the Act': Justice French in Trade Practices Commission v CSR Ltd, ATPR 41-076 at 52,152 [1991], quoted in Corones, supra note 20.

${ }^{47}$ OECD, REPORT ON THE NATURE AND IMPACT OF HARD CORE CARTELS, supra note 3, at 3.

48 In relation to specific deterrence, most evidence supports the view that criminal penalties, including incarceration, do not provide effective specific deterrence; that is, punishment, once received, will not necessarily deter a person from re-offending. It is, therefore, unlikely that harsher penalties will affect the rate of recidivity in this area. See The Panel on Research on Deterrent and Incapacitative Effects, Incapacitation, in DETERRENCE AND INCAPACITATION, 66 (Alfred Blumstein, Jacqueline Cohen and Daniel Nagin eds, 1978) and Mirko Bagaric, Incapacitation, Deterrence and Rehabilitation: Flawed Ideals or Appropriate Sentencing Goals, 24 CRIMINAL L.J. 19, 35-5 (2000).

49 In other words, the evidence suggests that generally there is no direct correlation between severity of the sanction and prevalence of the offence. See further Clarke \& Bagaric, supra note 45, at 192-209. It appears that most offenders commit crimes in response to situational factors such as opportunities and transient motives. Where this is so, there is no firm evidence that increasing penalty levels result in a reduction in crime. See: Frank E. ZiMring AND Gordon J. HAWKins, DETERRENCE: The LEGAL THREAT In CRIME CONTROL 29 (1973), Nigel WALKER, SENTENCING IN A RATIONAL SocIETy 60-61, 191 (1969), Roger Hood, The Death Penalty: A World Wide Perspective ch 6 (1996) and ANDREW VON HIRSCH AND ANTHONY BOTTOMS, CRIMINAL DETERRENCE AND SENTENCE SEVERITY 47 48 (1999).
} 
level of criminal conduct exists, it is in the context of offences - such as white collar offences - where the offender has the time, inclination and resources to do a cost-benefit analysis. ${ }^{50}$

In these cases, for a penalty to provide an effective deterrent the expected gain from the contravention must exceed the gain from the violation. ${ }^{51}$ The current penalty regime in Australia, combined with the small risk of detection, does not meet this requirement: ${ }^{52}$

The fact that the same companies and one individual involved in pricefixing in ACCC $v$ Pioneer Concrete (Qld) Pty Ltd had engaged in the same conduct before suggests that pecuniary penalties alone are not having a deterrent effect. ${ }^{53}$

\footnotetext{
50 Recently, the New Zealand Ministry of Commerce took the view that 'the arguments are relatively strong for assuming a high degree of rationality when firms make decisions about whether to comply with a competition law': MinISTRY OF COMMERCE (NZ), PENALTIES, REMEDIES AND COURT PROCESSES UNDER THE COMMERCE ACT 1985: A DisCUSSION DOCUMENT 7 (1998). See also McNeill, supra note 11: 'Although there are many moral people in business ... some businesses and business people need an external incentive to comply with the law - a risk benefit analysis that weights heavily against involvement in unlawful cartels'.

${ }_{51}$ Wouter P.J. Wils, Does the effective enforcement of Articles 81 and 82 EC require not only fines on undertakings but also individual penalties, in particular imprisonment, Paper presented at the EU Competition Law and Policy Workshop/Proceedings, European University Institute 11 (2001). See also Stuart M. Chemtob, Antitrust Deterrence in the United States and Japan, Paper presented at a Conference on Competition Policy in the Global Trading System: Perspectives from Japan, the United States, and the European Union, Washington DC 3 (June 23, 2000), available at < http://www.usdoj.gov/atr/public/speeches/5076.pdf>.

52 The increased penalties provided for in the Trade Practices Legislation Amendment Bill (No. 1) 2005 will come closer to approximating optimal penalties for price fixing but will still not be sufficient to constitute an effective deterrent.

${ }^{53}$ Corones, supra note 20, at 164: ‘ ... The message that needs to be conveyed is that from an individual manager's point of view, price-fixing and collusive tendering do not pay. They cost. And the cost is so high that the conduct is not worth contemplating.' See also Energex, supra note 7, at 6, Round, supra note 7, at 123 ('The fact that [price-fixing] is still quite common [in Australia] suggests that to a rational price-fixer the expected gains from colluding on prices with rivals exceed the expected costs of being detected, prosecuted and found in breach of the Act') and Robert Baxt, Thinking about Regulatory Mix Companies and Securities, Tax and Trade Practices, in Business REgUlation AND AUSTRALIA's FUTURE 124-127 (Peter Grabosky and John Braithwaite eds, 1993). Compare BP, Submission to the Review of the Provisions of the Trade Practices Act 1974, Public Submission 47, Trade Practices Act Review, 5 (2002) ('...current penalties provide sufficient deterrence'); Shell Australia, Submission to the Commission of Inquiry into the Trade Practices Act 1974, Public Submission 14, Trade Practices Act Review, 1, 7-8 (2002) (' $\ldots$ there would be very few corporations or individuals where the prospect of a penalty [the size of the current maximum] would not act as an adequate deterrent'); Vodafone, Submission to the Trade Practices Act Review, Public Submission 60, Trade Practices Act Review, 6 (2002) ('Financial penalties against both the individual and the company are sufficient deterrents against anticompetitive actions'); Business Council of Australia, Submission to the Dawson Review of the Trade Practices Act 1974 and Its Administration, Public Submission 71, Trade Practices Act Review, 117 (2002) ('the severe penalties which currently apply for those offences are an adequate deterrence') and Australian Chamber of Commerce and Industry, ACCI Submission to the Dawson Committee Review of the Trade Practices Act, Public Submission 104, Trade Practices Act Review, 85-88 (2002).
} 
The OECD has also observed that the maximum fines found in the laws of many countries dealing with cartel conduct 'may not be sufficiently large' 54 and that 'available data indicate that larger sanctions are required to achieve effective deterrence.' 55

In relation to corporations it is unlikely that any financial penalty alone - even the vastly increased pecuniary penalties planned by the Government - could provide an effective deterrent because, to do so, it would need to be so high as to be impossible in practice. ${ }^{56}$ Roughly, given the difficulty of detection and the expected gains from cartel conduct over the average duration of an undetected cartel, it has been estimated that the figure required to provide effective deterrence on a cost-benefit analysis would be unreasonably high ${ }^{57}$ in many cases exceeding the corporation's ability to pay. The result of this would be to reduce deterrence value, ${ }^{58}$ remove a competitor from the market and penalise the wrong people; namely shareholders, creditors and, ultimately, consumers. ${ }^{59}$

As realistic financial penalties for corporations alone are not sufficient to provide effective deterrence against cartelisation, the question then becomes, what level of penalty is required in order for individuals to consider the cost of becoming involved in unlawful cartels so high as to make it not worthwhile? Again, the current civil pecuniary penalties are clearly insufficient and higher civil penalties, while possibly providing some additional deterrence, could not, within a reasonable range, provide an effective deterrent for several reasons. First, as is the case for corporations, the individual may be 'judgement-proof' - unable to 'pay the mini-

\footnotetext{
54 OECD, REPORT ON THE NATURE AND IMPACT OF HARD CORE CARTELS, supra note 3, at 4. That is, they may not be large enough 'to accommodate multiples of the gain to the cartel, as recommended by many experts'

${ }^{55} I d$. at $5,16$.

${ }^{56}$ Wils, supra note 51, at 11-12: 'The expected fine is that imposed if the violation is detected and punished, multiplied by the probability of detection and punishment. The gain, which the firm obtains from the violation, divided by the probability of being fined, thus constitutes a floor below which fines will generally not deter.' [footnotes omitted].

57 'Assuming a $10 \%$ price increase, and a resulting increase in profits of $5 \%$ of turnover, a 5-year duration and a $16 \%$ probability of detection and punishment, the floor below which fines will generally not deter price-fixing would be in the order of $150 \%$ of the annual turnover in the products concerned by the violations.' [footnotes omitted]: Wils, supra note 51, at 13. For further detailed discussion of optimal penalties for competition law contraventions see MINISTRY OF COMMERCE (NZ), supra note 50, at 8-11. See also Dawson Report, supra note 31, at 160-161.

${ }^{58}$ It has been observed that if, between 1955 and 1993, optimal fines had been imposed on firms convicted of price-fixing ' $58 \%$ of the firms would not have been able to survive ... without becoming technically insolvent': Wils, supra note 51, at 15, citing C. Craycraft, J.L Craycraft JL and J.C. Gallo, Antitrust Sanctions and a Firm's Ability to Pay, 12 REVIEW OF INDUSTRIAL ORG. 171. See also Stephen Calkins, Corporate Compliance and the Antitrust Agencies' Bi-Modal Penalties, 60 LAW AND CONTEMP. PROBS. 127, 143 (1997) ('... were the numbers raised sufficiently high, the great majority of individual defendants would be unable to pay').

59 For further discussion see Wils, supra note 51, at 16, 18, ACCC, Submission to the Trade Practices Act Review, supra note 22, at 34, Gerald Acquaah-Gaisie, Corporate crimes: Criminal intent and just restitution, 13 AUSTRALIAN J. OF CORP. L. 219 (2001) and OECD, REPORT ON THE NATURE AND IMPACT OF HARD CORE CARTELS, supra note 3, at 16.
} 
mum financial penalty required for effective deterrence'. ${ }^{60}$ Second, even if an individual is able to pay the fine imposed, there is an additional problem of indemnification - it is relatively easy for the corporation to indemnify, at least indirectly, an executive or employee that has been financially penalised for anti-competitive conduct. $^{61}$ In addition, most executives who have admitted or have been held to have engaged in cartel conduct have also managed to retain their existing employment or find other equivalent, or more rewarding, employment elsewhere. ${ }^{62} \mathrm{Fi}$ nally, the potential gains of cartelising, given the low detection rate, might still appear too enticing for certain individuals. In this respect, even the Business Council of Australia (BCA) has accepted that at present under the current system 'there is a danger that [conspirators] may think the profits from price-fixing are going to outweigh any fines'. ${ }^{3}$

Because financial penalties alone are not capable of providing an effective deterrent against engaging in cartel conduct, alternative penalties need to be considered. One possibility is imprisonment. ${ }^{64}$

A conventional risk-benefit analysis breaks down when the possibility of imprisonment or other criminal sanctions are introduced. It is difficult to impose a dollar amount on the loss of freedom or the stigma ${ }^{65}$ associated with serving time in prison

\footnotetext{
${ }^{60}$ See Wils, supra note 51, at 10. See also Arie Freiberg, Monetary Penalties under the Trade Practices Act 1974 (Cth), 11 AUSTRALIAN B.L.REV. 4, 16-18 (1983) discussing the capacity of an individual defendant to pay penalties under the trade practices and the consequences of inability to pay.

${ }^{61}$ While the Dawson Committee has recommended that legislation be amended to prohibit corporations from 'indemnifying, directly or indirectly, officers, employees or agents against the imposition of a pecuniary penalty upon an officer, employee or agent' (Dawson Report, supra note 31, at 165 rec 10.2.3), Wils notes that such prohibitions may easily be avoided: '... firms can relatively easily indemnify their agents for any threat of fines or any fines effectively imposed, thus taking away the deterrent effect of the penalty on the individuals concerned ... the firm can relatively easily compensate the manager in advance for taking the risk and/or indemnify him ex post when he has to pay the fine' (Wils, supra note 51 , at 27 ).

${ }_{62}$ The Dawson Committee has recommended that Courts be given the option of excluding individuals found guilty of hard core cartel conduct from being a director of a corporation or being involved in its management (Dawson Report, supra note 31, at $165 \mathrm{rec}$ 10.2.2). This recommendation now forms part of the current Trade Practices Legislation Amendment Bill (No. 1) 2005. This may reduce the ease with which individuals may obtain future similar employment, however it is unlikely to cover all avenues of involvement in business activity.

${ }^{63}$ Blair Speedy, Industry worried by cartel penalties, THE AUSTRALIAN, Feb. 3, 2005 (online) at <http://www.theaustralian.news.com.au/printpage/0,5942,12127457,00.html> (quoting Steven Munchenberg, Business Council of Australia general manager of government and regulatory affairs).

${ }^{64}$ See, e.g., Wils, supra note 51, at 27 ('... there is ample evidence that the threat of imprisonment constitutes a very effective deterrent for antitrust offences').

65 A distinguishing feature of the criminal law is that it 'carries, and is designed to carry, a stigma effect': Wils, supra note 51, at 33. See also Small Business Development Corporation, Submission to the Trade Practices Act Review, Public Submission 84, Trade Practices Act Review, 2 (2002) ('The social and commercial stigma attaching to imprisonment for breaching the law can be significant') and Gerard Lynch, The Role of Criminal Law in Policing Corporate Misconduct, 60 LAW AND CONTEMP. PROBS. 23, 39-40 (1997). The Dawson Report also noted the moral condemnation associated with criminal punishment: 'A criminal conviction represents the condemnation of society in a way that the imposition of a civil penalty cannot ...' (Dawson Report, supra note 31, at 158).
} 
or receiving a criminal conviction. ${ }^{66}$ In the case of senior businessmen, the threat of imprisonment is likely to prove particularly potent. ${ }^{67}$ It is, therefore, likely that the threat of criminal sanction, in the form of a fine and/or prison term are more likely to prove a more effective deterrent against cartel conduct than any amount of pecuniary penalty. Even the BCA, who have expressed reservations at the introduction of criminal penalties, ${ }^{68}$ have conceded that the prospect of going to jail is going to make individuals think a lot harder about whether they engage in illegal activity. ${ }^{69}$

\section{B Fairness and consistency}

Another key justification for introducing criminal sanctions for cartel conduct is fairness and consistency. ${ }^{70}$ The law presently criminalizes similar types of conduct - much of which is less harmful to society - and therefore cartel conduct should not be exempt from criminal prosecution. While this argument is not without flaws, ${ }^{71}$ it is inherently difficulty to justify criminalising, for example, common theft, which may cost an individual victim a few hundred or even thousand dollars, while leaving cartel conduct, which produces multiple victims suffering combined losses often into the millions of dollars, immune from criminal sanction. Most notably cartels lead to consumers paying more for goods and services and, in this way, unfairly deprives consumers of property - in the form of money. ${ }^{72}$ Conservative estimates put the harm of cartels in excess of many billions of US dollars annually. $^{73}$ In this respect it has often been observed that

\footnotetext{
${ }^{66}$ See Chemtob, supra note 51, at 19 ('... criminal enforcement has the potential to improve deterrence markedly by introducing non-monetary costs into the equation ...'). Compare Australian Industry Group, Submission to Committee of Enquiry into the Competition Provisions of the Trade Practices Act 1974 , and their Administration, Public Submission 109, Trade Practices Act Review, 61 (2002) ('it is still unsound logic ... to suggest that imprisonment of individual executives or managers engaged in the cartel activity for the corporation will act as a more effective deterrent to other corporations or individuals').

67 See Arthur Liman, The Paper Label Sentences: Critique, 86 YALE L.J. 619, 630-631 (1977) quoted in Wils, supra note 51, at 28. See also Neal Kumar Katyal, Deterrence's Difficulty, 95 MiCH. L. REV. 2385, 2416 (1997) who notes that 'the threat of jail has different meanings for different people. ... For users of moderate wealth, the threat of jail may provide more of a deterrent than the monetary cost.'

${ }^{68}$ See Speedy, supra note 63 and, in relation to corporate fines, Toni O'Loughlin, Costello backs jail sentences for executives, THE AUSTRALIAN FINANCIAL REVIEW, Feb. 2, 2005, at 1, 4.

69 Rowland, supra note 40, quoting Business Council of Australia's General Manager of Government and Regulatory Affairs, Stephen Muchenburg. Overseas experience also suggests that the imposition of criminal penalties, particularly in combination with a leniency policy, helps to promote both deterrence and detection of cartels.

${ }^{70}$ See Clarke \& Bagaric, supra note 45 for a more detailed discussion of the possible justifications for introducing criminal penalties for this type of conduct.

${ }^{71}$ See Clarke \& Bagaric, supra note 45, at 200-202.

${ }^{72}$ See also Acquaah-Gaisie, supra note 59 ('Conventional crime may touch only a few people, but corporate crimes can devastate many lives....).

${ }^{73}$ OECD, REPORT ON THE NATURE AND IMPACT OF HARD CORE CARTELS, supra note 3, at 2. See also OECD, FIGHTING HARD CORE CARTEls: HARM, EFFECTIVE SANCTIONS AND LENIENCY PROGRAMMES 81 (2002): 'It remains difficult to place a monetary value on the harm [caused by cartels], but it is surely significant, amounting to billions of dollars annually' and, (at 72) 'the amount of commerce affected by just 16 large cartel cases reported in the OECD survey exceeded USD 55 billion world-wide. ... it is clear that the magnitude of harm from cartels is many billions of dollars annually.'
} 
Hard-core collusion is morally reprehensible. It is a form of theft and little different from other white collar crimes (including insider trading and obtaining a benefit by deception) that already attract criminal sentences. ${ }^{74}$

It is not unusual for anti-competitive violations to involve far greater sums than those that may be taken by thieves or fraudsters, and the violations can have a far greater impact upon the welfare of society. ... ${ }^{75}$

The Government takes a similar stance with the Treasurer describing hardcore cartels as 'a very sophisticated way of essentially stealing. ${ }^{76}$

Other forms of white collar crime can and do result in criminal penalties. Even within the TPA itself, conduct such as false or misleading representations, ${ }^{77}$ bait advertising, ${ }^{78}$ referral selling ${ }^{79}$ and pyramid selling ${ }^{80}$ carry potential criminal penalties. This different treatment, despite the fact that cartels are clearly 'capable of doing far more damage to our economy and to consumers than many of the worst consumer scams, ${ }^{81}$ is anomalous and unjustified.

Criminalisation of cartel conduct would, therefore, go someway to addressing claims that the current criminal law regime benefits those capable of more complex and sophisticated theft or fraud by treating their conduct as forgivable by way of civil pecuniary penalties while other less sophisticated (and less financially devas-

${ }_{74}$ ACCC, Submission to the Trade Practices Act Review, supra note 22, at 24.

75 ACCC v. ABB Transmission and Distribution Limited (No. 2) FCA 559, I[28 [2002] per Justice Finkelstein, cited in ACCC, Submission to the Trade Practices Act Review, Public Submission 50, Trade Practices Act Review, 25 (2002). The quote continues: 'Cartels ... enrich participants at the expense of consumers. They injure consumers by raising prices above the competitive level and reducing output. Cartels can be very harmful across wide areas of an economy by artificially creating market power and leads to inefficient and wasteful allocation of resources ... They are blatant frauds on consumers'. See also Corones, supra note 20 and OECD, FIGHTING HARD CORE CARTELS, supra note 73, at 71-81.

76 ABC Television, Tougher penalties for price-fixing business cartels (Feb. 2, 2005) available at $\mathrm{ABC}$ online - The 7:30 Report: http://www.abc.net.au/7.30/content/2005/s1294813.htm. See also Corones, supra note 20, at 160: 'The objections to [price-fixing and collusive tendering] are both economic and ethical. At the economic level, price-fixing and collusive tendering entail a loss of economic efficiency and a financial burden on the purchaser, ultimately the consumer or taxpayer. Ethically, they involve deception for financial gain.'

77 Trade Practices Act, 1974, § 75AZC (Cth).

78 Trade Practices Act, 1974, § 75AZJ (Cth).

79 Trade Practices Act, 1974, § 75AZK (Cth)

80 Trade Practices Act, 1974, § 75AZO (Cth). These activities are criminalized despite the apparent recognition (through the size of penalty available) that, financially at least, they are less harmful to society than contraventions of Part IV. The current maximum criminal penalty for breaches of these sections is 10,000 penalty units in each case (equivalent to $\$ 1.1$ million), significantly less than the maximum civil penalty available for breaches of Part IV.

${ }^{81} \mathrm{McNeill}$, supra note 11. Graeme Samuel has also described cartels as 'a cancer on the economy, a silent extortion' and 'amongst our highest priorities': Graeme Samuel, Future work of the ICN: Introduction to the $6^{\text {th }}$ International Cartels Workshop, Speech delivered at the $3^{\text {rd }}$ International Competition Network Annual Conference, Seoul (April 22, 2004), available at

<http://www.accc.gov.au/content/index.phtml/itemId/500257/fromItemId/8973>. 
tating) criminals may find themselves behind bars or at least facing criminal conviction and its associated stigma. ${ }^{82}$

Criminalisation would also bring hard-core cartelisation in line with other comparable (or even less harmful) white collar crimes and would also recognise it as at least as morally reprehensible as other forms of financial crime.

\section{International best practice}

The final key justification advanced is that criminalising cartel conduct would bring Australia into line with best practices in cartel enforcement around the world. ${ }^{83}$ Some of the most successful cartel regulators employ criminal penalties, frequently in combination with leniency programs, as an effective mechanism in deterring and identifying cartel conduct. Many of these regimes also employ concurrent civil remedies, as is proposed for Australia. The United States, for example, has criminalised cartel conduct since the enactment of the Sherman Act of 1890 and has recently introduced tougher criminal penalties via the Antitrust Criminal Penalty Enhancement and Reform Act of 2004 which increases the maximum corporate fine from $\$ 10 \mathrm{~m}$ to $\$ 100 \mathrm{~m}$, the maximum individual fine from $\$ 350,000$ to $\$ 1 \mathrm{~m}$ and the maximum prison term from 3 years to 10 years. ${ }^{84}$

The United Kingdom, on the other hand, has only recently introduced criminal penalties for cartel conduct ${ }^{85}$ which, for individuals, could result in an unlimited criminal fine and/or up to 5 years imprisonment. A defendant can be convicted if,

\footnotetext{
${ }^{82}$ See, e.g., Wils, supra note 51, at 28: ('... imprisonment, being society's most onerous and stigmatic punishment, should not be withheld from those with economic power and social status, when it is regularly applied to the poor and powerless ...'); Australian Consumers Association, Submission on the Review of the Competition Provisions of the Trade Practices Act 1974, Public Submission 105, Trade Practices Act Review, 7 (2002) ('In the interests of equality of justice, there is no reason that corporate criminals engaged in cartel behaviour, which is a form of theft, should be immune from a jail sentence which is faced by other thieves') and Lynch, supra note 65, at 39-40.

${ }^{83}$ See Fels, The Trades Practices Act and world's best practice, supra note 1: 'The Australian law needs to remain in step with the law applying in many of its major trading partners'.

${ }^{84}$ See further Scott D. Hammond, An Overview of Recent Developments in the Antitrust Division's Criminal Enforcement Program, Speech to the American Bar Association, Kona, Hawaii, (Jan. 10 2005), available at $\langle\mathrm{http} / / / \mathrm{www} . u s d o j . g o v /$ atr/public/speeches/207226.pdf $\rangle$. The new Act passed into law on 23 June 2004. However, even prior to its enactment, in the case of both individuals and corporations, the fine was capable of being increased to the higher of either twice the pecuniary gain enjoyed by the defendant or twice the gross loss to victims of the conduct: see ACCC, Submission to the Trade Practices Act Review, supra note 22, at 57. This facilitated very large fines for antitrust breaches, including a fine of $\$ 500$ million against F. Hoffmann-La Roche for it's role in the international vitamin cartel (this was 'the largest single fine imposed in a DOJ case for any crime under any statute': Scott D. Hammond, From Hollywood to Hong Kong - Criminal Antitrust Enforcement is Coming to a City Near You, Paper presented at the Antitrust Beyond Borders Conference, Chicogo, Illinous 3 (Nov. 9, 2001)). See also Press Release, Department of Justice (US), F Hoffmann-La Roche and BASF Agree to Pay Record Criminal Fines for Participating in International Vitamin Cartel (May 20, 1999), available at <http://www.usdoj.gov/opa/pr/1999/May/196at.htm>. In relation to individual penalties, fines of up to $\$ 7.5$ million have been awarded, in addition to jail time: Dan Ackman, Taubman Sentenced To One Year - Plus A Day, FORBES, NeW YORK, April 22, 2002, at

<http://www.forbes.com/2002/04/22/0422taubman.html>.

${ }^{85}$ Enterprise Act, 2002, (UK).
} 
targeting the United Kingdom, "he "dishonestly" agrees with one or more persons to make or implement, or to cause to be made or implemented', ${ }^{86}$ a horizontal agreement to:

- Directly or indirectly fix the price of goods or services;

- Limit or prevent supply or production of goods or supply of services;

- Allocate customers or markets; or

- Rig contract bids. ${ }^{87}$

This criminal offence is separate to the civil prohibition and does not depend upon a breach of the existing civil laws. Corporations are not subjected to criminal prosecution. It is too soon to gauge the full effectiveness of this new regime as a deterrent against cartel conduct.

A number of other countries, including Canada, France, Ireland and Japan also provide for criminal fines and jail terms for cartel conduct and others are considering their introduction. ${ }^{88}$

These three key justifications all appropriately favour the introduction of criminal penalties. Consequently, the following evaluation of the Government's proposals will focus on how these penalties are being introduced and will assume the threshold issue of whether any criminal sanctions are appropriate for cartel conduct can be answered in the affirmative.

\section{The Government's Proposal: The Cartel Offence}

The Government's proposal for the criminalisation of cartels will

prohibit a person from making or giving effect to a contract, arrangement or understanding between competitors that contains a provision to fix prices, restrict output, divide markets or rig bids, where the contract, arrangement or understanding is made or given effect to with the intention of dishonestly obtaining a gain from customers who fall victim to the cartel. ${ }^{89}$

The civil system of cartel prohibition will also be significantly changed. It is unclear yet precisely how the existing provisions dealing with cartel conduct will alter, but the Government has indicated that 'revised civil per se prohibitions for cartel behaviour will reflect the OECD recommendations, so that this separately

\footnotetext{
${ }^{86}$ Enterprise Act, 2002, § 188(1) (UK).

${ }^{87}$ Enterprise Act, 2002, § 188(1) (UK).

${ }^{88}$ See, e.g. Competition Act (Canada) (imprisonment of up to 5 years available), Competition Act, 2002 (Ireland) (imprisonment of up to 5 years available) and the Antimonopoly Law, 1947 (Japan) (imprisonment of up to 5 years available). Note, however, that to date jail time has only been imposed in the United States and Canada.

${ }^{89}$ Treasurer, Criminal Penalties for Serious Cartel Behaviour, supra note 2.
} 
addresses cartel activity' with the intent that this will provide a more effective civil system and will ensure 'consistency in the way in which the revised civil prohibitions and the new criminal offence are applied.'

The Government intends criminal prosecution to be restricted to 'serious' cartel conduct to be, with what the Government refers to as more 'minor' cartel conduct being dealt with through the civil system. To this end the Government has indicated that the DPP and ACCC are to enter into a public Memorandum of Understanding (MOU) 'establishing procedures for the investigation of the cartel offence and the circumstances in which the ACCC will refer a case to the DPP'. ${ }^{90}$

For the ACCC, relevant factors for determining whether to refer the matter to the DPP for prosecution will include the impact of the cartel and the scale of detriment caused to consumers and the public, and previous admissions to or convictions for cartel conduct'. It will also include controversial thresholds, with the ACCC to consider whether

the value of affected commerce exceeded \$1 million within a 12 month period, that is, where the combined value for all cartel participants of the specific line of commerce effected by the cartel exceeds $\$ 1$ million within a 12 month period. For bid rigging cases, the value of the successful bid or series of bids would need to exceed $\$ 1$ million within a 12 month period. ${ }^{91}$

Once referred, the MOU would further require the DPP to consider, before deciding whether to prosecute,

the impact of the cartel on the market, the scale of the detriment caused to consumers or the public, and whether any of the alleged members of the cartel have previously been found by a criminal or civil court, or admitted, to having engaged in cartel behaviour. ${ }^{92}$

The ACCC will also be required to issue separate Guidelines indicating when they will proceed with criminal investigation which are to be consistent with the MOU. ${ }^{93}$

As a consequence of these proposed guidelines, criminal prosecution for contraventions of the cartel offence, while prima facie applying to all business, regardless of size, or the amount of commerce affected, will, in practice, be restricted to larger businesses where a significant volume of commerce has been affected.

The Government has also indicated that appropriate whisleblower protection, through an immunity program, is to be made available to assist in uncovering cartels, with guidelines to be formulated to determine when such immunity would

\footnotetext{
${ }^{90} I d$.

${ }^{91} I d$.

${ }^{92} I d$.

${ }^{93}$ Id.
} 
be granted. This would also involve amendment of the DPP's Prosecution Policy to 'enable immunity to be granted at an early stage in an investigation'. ${ }^{94}$

Finally, the Government has made clear that conduct currently permitted under the TPA through a series of exemptions or through the authorisation process will also be exempt from criminal prosecution.

\section{Vi Evaluation of Government Proposal}

There are a number of aspects of the Government's recommendations which require further evaluation. In particular, this section will address the Government's definition of cartel, the dishonesty element, the proposal to limit prosecution to 'serious' breaches of the cartel offence, the level of penalty, exclusions from prohibitions, the management of concurrent civil and criminal penalties, the roles of the ACCC and DPP and the whistleblower protection plan.

\section{A Definition of cartel conduct and placement in the TPA}

Leaving aside the issue of dishonesty, which will be discussed further below, the Government indicated it wished to "proscribe serious cartel conduct in a manner consistent with international best practice ${ }^{95}$ which it considered could be achieved by a adopting the OECD's definition of 'hard-core cartel'. 96 The OECD Recommendation Concerning Effective Action Against Hard Core Cartels defines a 'hard core cartel' as:

an anticompetitive agreement, anti-competitive concerted practice, or anticompetitive arrangement by competitors to fix prices, make rigged bids (collusive tenders), establish output restrictions or quotas, or share or divide markets by allocating customers, suppliers, territories, or lines of commerce [but does not include] agreements, concerted practices or arrangements that

i) are reasonably related to the lawful realisation of cost-reducing or output-enhancing efficiencies,

ii) are excluded directly or indirectly from the coverage of a Member country's own laws, or

\footnotetext{
${ }^{94} \mathrm{Id}$.

${ }^{95} \mathrm{Id}$.

${ }^{96}$ A similar approach was taken in the United Kingdom where the Report which ultimately led to the introduction of criminal sanctions recommended that 'hard-core' cartels be defined by the type of conduct involved, namely, price fixing, market sharing, bid-rigging and agreements to restrict output or set quotas, subject to that conduct that already benefits from specific exemptions. The Report further concluded that it was preferable to incorporate a concept of 'dishonesty' in entering into agreements, rather than to seek to rely on economic elements, such as lessening of competition, for purpose of determining the seriousness or otherwise of the conduct: ANTHONY HAMMOND AND ROY PENROSE, PROPOSED CRIMINALISATION OF CARTELS IN THE UK, 4, 9 (Office of Fair Trading, November 2001).
} 
iii) are authorised in accordance with those laws. ${ }^{97}$

The nature of the conduct as 'hard core' is, therefore, determined solely by the type of cartel involved and does not involve any consideration of the size of the cartel or its participants. In accordance with this recommendation, the Government has proposed that the new cartel offence and amended civil per se provisions capture price fixing, output restrictions, bid rigging and market sharing. In particular, it would involve proof of the following:

- $\quad$ an agreement is made between or given effect to by two or more parties;

- the parties who made the agreement are competitors in the supply or acquisition of goods or services in a particular market; and

- the agreement contains a provision to fix prices, restrict output, share or divide markets or rig bids. ${ }^{98}$

The Government notes that the four forms of conduct referred to will be 'explicitly defined' in the offence, though no details have yet been provided. An additional dishonesty element, to be discussed below, will be incorporated into the criminal offence but not the new civil prohibition on cartel conduct. ${ }^{99}$

The types of conduct to be captured are appropriate and consistent with the OECD Recommendation and with the prohibited conduct in must other jurisdictions employing criminal penalties for cartelisation. The devil, of course, is in the detail, and the Government has not yet indicated how these forms of conduct will be defined. As far as possible they should be defined in a manner that would be consistent with existing civil provisions in the TPA. This would enable reference to an existing body of precedent and assist in providing business with some certainty as to the forms of conduct to be avoided. Provided this course is adopted there is unlikely to be any real controversy surrounding the definition.

\footnotetext{
97 OECD, RECOMMENDATION OF THE COUNCIL CONCERNING EFFECTIVE ACTION AGAINST HaRd CORE CARTELS (adopted by the Council at its $921^{\text {st }}$ Session on Mar. 25, 1998), rec. A(2).

98 Treasurer, Criminal Penalties for Serious Cartel Behaviour, supra note 2.

99 In relation to dishonesty, the Law Council of Australia recommended the following elements be present in the cartel offence: 'a person who dishonestly makes or gives effect to a contract arrangement or understanding with one or more other persons which the person and at least one other party to the contract, arrangement or understanding intends to have the effect of fixing, controlling or maintaining prices for the goods or services, and the person and at least one other person to the contract, arrangement or understanding acquire or supply the particular goods or services to persons (other than each other) in competition with each other': Law Council of Australia, Business Law Section, Submission to Working Party on Penalties for Cartel Behaviour, 10-11, I2.7 (Dec. 12, 2003). Note that the Law Council recommended limiting the offence to price fixing cartels because of fears of inconsistency with the operation of the civil per se offence.
} 


\section{B The dishonesty element}

The ACCC initially recommended that dishonest intent should not form a necessary element of an offence of hard core cartelisation in Australia, ${ }^{100}$ but subsequently supported such a requirement. ${ }^{101}$ The Dawson Committee also expressed reservations about dishonesty element on the grounds that it might cause difficulty for jurors.

The Government's proposal does, however, incorporate a dishonesty element into the cartel offence, based on the belief that dishonesty is at the 'heart of serious cartel conduct', involving the deceit of customers who purchase goods or services into believing that their price and supply were determined by competition and not collusion. $^{102}$

Incorporation of the dishonesty element is also consistent with the approach recently adopted in the United Kingdom and, especially given the proposed uniform definition for cartel conduct under the civil regime, provides an appropriate distinction between conduct that is criminal and that which remains subject to civil penalties alone. ${ }^{103}$

Despite the ACCC and the Dawson Committee's reservations, it is appropriate to incorporate some form of mental element into a criminal offence of this nature and dishonesty, having an established definition under the Criminal Code, is unlikely to cause jurors too many difficulties. ${ }^{104}$ The Criminal Code essentially provides that the dishonesty requirement will be proved if:

a jury is satisfied that the cartel arrangement was dishonest according to the standards of ordinary people, and the defendant knew it was dishonest according to those standards. ${ }^{105}$

The Government has also listed several indicators of dishonesty, including

- deception (such as lies or misleading statements),

\footnotetext{
${ }^{100}$ The main reasoning given by the ACCC for eliminating dishonesty as a requirement is that a 'business is highly unlikely to enter a cartel agreement bona fide': ACCC, Submission to the Trade Practices Act Review, supra note 22, at 45. The Dawson Committee did not make recommendations as to the specific requirements of a criminal offence and reached no conclusion about the desirability or otherwise of including a dishonesty requirement: Dawson Report, supra note 31, ch 10.

${ }^{101}$ In a subsequent submission the ACCC supported a dishonest requirement: Dawson Report, supra note 31 , at 155 .

${ }^{102}$ Treasurer, Criminal Penalties for Serious Cartel Behaviour, supra note 2.

${ }^{103}$ In this respect the Law Council of Australia submitted that seriousness should be gauged by moral culpability and further, that '[a] requirement that the person intended to fix prices, or to restrict supply, of goods or services appropriately assists in distinguishing criminal from non-criminal arrangements': Law Council of Australia, Submission to Working Party, supra note 99, at 9-10, 9[2.7.

${ }^{104}$ See also Treasurer, Criminal Penalties for Serious Cartel Behaviour, supra note 2 ('dishonesty is an established concept in Australian criminal law and is widely used in corporations and fraud offences... appropriately captures the genuinely criminal nature of serious cartel conduct.')

${ }^{105}$ Treasurer, Criminal Penalties for Serious Cartel Behaviour, supra note 2.
} 
- making or relying upon representations or promises that are known to be false or which would not be carried out,

- concealing facts that there is a duty to disclose, and

- $\quad$ engaging in conduct that the defendant knows they have no right to engage in. ${ }^{106}$

It is likely to be very rare that a corporation or individual engaged in cartel conduct of the kind proposed to be prohibited will not have known that what they were doing was wrong; for competitors entering into cartels dishonesty is normally inherent in the conduct itself, which explains the highly secretive nature of cartels. ${ }^{107}$ Consequently, a basic 'dishonesty' requirement is also unlikely to prove a large hurdle when seeking to obtain a conviction, provided all other elements of the offence are proved.

The Government has, however, gone one step further than merely requiring dishonesty. It has indicated that the dishonesty must relate to the obtaining of a

pecuniary or non-pecuniary gain, either for the defendant or for another person. It must be intended to obtain the gain from a person or class of persons likely to acquire or supply the goods or services to which the cartel relates. $^{108}$

Not only is it unclear how this requirement would be incorporated into the offence itself, such a requirement would also complicate what is otherwise a relatively straightforward concept with an existing jurisprudence. If a corporation or individual engages in conduct that satisfies the other elements of the offence and is dishonest in doing so - that is, it is engaged in with the knowledge that it is wrong to do so - that should be sufficient. In particular, it should be of no consequence from whom conspirators intend to gain. This could lead to all manner of arguments seeking to justify cartel conduct. For example, a corporation, or an individual could engage in blatant price fixing, knowing what they were doing was wrong, but claim that it was done for altruistic purposes, such as ensuring that their business did not fail as a result of 'cut throat' competition, thereby rendering their workers unemployed. ${ }^{109}$ It is possible to imagine a number of other public benefits that parties to a cartel might claim to have intended. ${ }^{110}$ How is a court - or, in particular, a jury -

106 Id.

107 Note that this does not require full knowledge of the offence itself or that would be contrary to the notion that ignorance of the law is no excuse. Thus, knowledge that conduct is 'wrong' does not necessarily mean knowledge that it is contrary to the criminal law.

${ }^{108}$ Treasurer, Criminal Penalties for Serious Cartel Behaviour, supra note 2.

109 These sorts of arguments have been advanced as justifications for price fixing in Australia and elsewhere. In Australia they currently do not constitute a defence to price fixing but may be argued as a public benefit in authorisation proceedings. See, for example TPC v. Service Station Association Ltd, 44 FCR 206 (1993) and United States v. Socony-Vacuum Oil Co, 310 US 130 (1940).

${ }^{110}$ Many other explanations have been put forth in the past as attempted justifications for price-fixing, most with little success. They include public safety (see National Society of Professional Engineers v. United States, 435 US 679 (1978)), the need to create countervailing power to that of suppliers or customers (see Re Australian Phosphate Purchasing Association 1 TPR 397 (1982)) and the need to fund 
to assess these? What level of intent must there be? Is it sufficient if an individual did not intend consumers to be out of pocket, but knew this would be an unfortunate but inevitable consequence of the conduct? Is it sufficient if the accused knew that they would obtain an immediate pecuniary gain, but did not have this as a long term goal? Is it the immediate or long term objective that is to be assessed?

Questions such as long-term/short-term intent have arisen from time to time within the existing competition law provisions and have generally caused problems and confusion, even in experienced federal courts; the potential for causing jurors confusion is very evident. For potential offenders it also unnecessarily blurs the lines between what is, and what is not, acceptable conduct.

The additional dishonesty elements are not necessary to confirm with OECD recommendations or with international best practice and simply complicate an issue, particularly one to be put before a jury, when there is nothing obvious to be gained. The Government should omit any such requirement beyond simple 'dishonesty' from the bill giving effect to these reforms and it should not appear in any of the proposed guidelines.

\section{Only serious breaches criminal?}

The suggestion that only 'serious cartel conduct' be targeted for criminal prosecution has, not surprisingly, caused considerable controversy. The Dawson Committee flagged early on that there were 'undeniable difficulties in defining a criminal offence which covers only serious cartel behaviour.' ${ }^{111}$ In particular, the issue of whether or not small business should be exempt from criminal provisions was debated in depth at the time of the Dawson Review, with the ACCC first submitting that only big business should be targeted but then changing their mind, recognising such distinction to be unacceptable. ${ }^{112}$ The Dawson Committee did not attempt to define the range of conduct that should be criminalised but did, sensibly, recommend that 'any criminal sanctions that are created should apply to all who engage in the cartel conduct and not just to large corporations'. ${ }^{113}$ The Law Council of Australia, in its submission to the Working Party, also dismiss duration, ${ }^{114}$ substantiality of the market ${ }^{115}$ and commerce affected, ${ }^{116}$ as measures of seriousness, instead focussing on moral culpability as the appropriate criteria. ${ }^{117}$

research and development and/or improve quality (see Re The Yarn Spinners' Agreement 1 All ER 299 [1959]). See further PhILIP ClaRKE AND STEPHEN CORONES, COMPETITION LAW AND POLICY: CASES AND MATERIALS 292-283 (1999).

${ }^{111}$ Dawson Report, supra note 31, at 154.

${ }^{112} I d$. at 154 .

${ }^{113} \mathrm{Id}$. at 163 .

${ }^{114}$ Law Council of Australia, Submission to Working Party, supra note 99, at 8, $9[2.4 .2$ (on the basis it would be too arbitrary).

${ }^{115} I d$. at 8, I $[2.4 .3$ (on the basis it would be too uncertain in its application).

${ }^{116} \mathrm{Id}$. at 8, $9[2.4 .4$ (on the basis it may not take into account the 'multiplier effect of a cartel affecting supply of an essential ingredient or component on very substantial downstream markets.')

${ }^{117} I d$. at 9, I[2.4.5. 
While the Government has followed these recommendations in relation to the proposed legislation itself, it has undermined them by proposing that the MOU between the DPP and ACCC and the additional ACCC guidelines on the cartel offence, limit the circumstances in which criminal action would be pursued to conduct where a significant amount of commerce was affected, thus ruling out some smaller business agreements which would otherwise fall within the legislation.

In particular, the Government has announced that the MOU will require the ACCC to consider, before referring a matter to the DPP for prosecution, whether:

- the alleged conduct was longstanding or had, or could have, a significant impact on the market in which the conduct occurred; or

- the alleged conduct caused, or could cause, significant detriment to the public, or a class thereof, or caused or could cause, significant loss or damage to one or more customers of the alleged participants ... ${ }^{118}$

In addition, the MOU will include monetary thresholds, outlined above, to assist the ACCC in determining what would constitute a 'significant impact on the market' or 'significant detriment to the public'. 119

Similarly, even when the ACCC does refer a matter to the DPP, the MOU will impose a separate requirement on the DPP to consider 'the impact of the cartel on the market' and 'the scale of the detriment caused to consumers or the public' in deciding whether or not to prosecute a cartel offence.

This is all designed, according to the Government, to enable 'proportionate response' with the 'most serious cartel conduct' being 'pursued under the criminal provisions, and other cartel conduct would be litigated civilly. ${ }^{120}$ As a consequence, while technically the criminal provisions will apply to all business - big or small - the Government has indirectly imposed a limitation on the application of the offence to only 'serious cartel conduct that causes large scale or significant economic harm'; ${ }^{121}$ thus, it is not all serious cartel conduct that will be pursued, but rather, only the most serious of the serious.

This distinction based on size or scale unjustified. First, cartel conduct captured by the cartel offence is already 'serious', by definition, and the proportionate response to criminal conduct is to apply a criminal penalty. The level of harm caused by the illegal conduct is more appropriately a matter for sentencing (as is the case with most criminal offences that can cause varying degrees of harm) and not for determining whether to pursue criminal prosecution in the first place. For example,

\footnotetext{
118 Treasurer, Criminal Penalties for Serious Cartel Behaviour, supra note 2.

${ }^{119}$ These thresholds are set out, above.

${ }^{120}$ Treasurer, Criminal Penalties for Serious Cartel Behaviour, supra note 2.

${ }^{121}$ Id. The Treasurer also notes that in the enforcement of the offence 'we actually look at the big operators' because they have the ability to distort markets: ABC Television, Tougher penalties, supra note 76.
} 
individuals guilty of speeding are subject to (at least) criminal fines regardless of whether or not they were exceeding the speed limit by $10 \mathrm{~km}$ or $100 \mathrm{~km}$; the fine is simply greater, the higher the speedometer reading.

The distinction also presumes that the more value of commerce affected the more damage incurred; in fact smaller cartels may have profound impact in, for example, smaller country towns where more harm may be caused to certain individual consumers in that town, compared to larger cartels that might inflict more total net damage, but that damage is diffused amongst a wider group of consumers or competitors. Thus, simply because the amount of commerce affected by price fixing may be small does not render the offence less serious for the purpose of defining what is to be criminal; all of these forms of conduct are serious. ${ }^{12}$

Second, the distinction is not needed in order to be consistent with international best practice; the OECD recommendations which simply define hard core - or serious cartel conduct by the type of conduct involved and nothing more. ${ }^{123}$ Even the Law Council of Australia, which has claimed, controversially, that 'not all price fixing or market sharing agreements could be classed as 'serious cartel conduct', ${ }^{124}$ nevertheless agrees that it is not suitable to define serious by the size of the business. ${ }^{125}$

Finally, the issue of fairness naturally arises when financial thresholds are introduced. It has been, correctly, asserted that small firms 'cannot be given a blanket exemption without raising real questions about equality under the law'. ${ }^{126}$

This is surely correct. The ACCC and/or DPP may choose not to proceed with criminal proceedings in certain cases, but this should not be decided based on some arbitrary measure of the value of commerce affected. This has the undesirably effect of suggesting to business that some 'serious cartels' are in fact not really all that serious. ${ }^{127}$ It is akin to saying that all speeding is criminal, but we will only fine those who exceed the speed limit by $20 \mathrm{~km}$ per hour or more. Such a public policy would reduce the deterrent effect of the offence and it is likely that there

122 See, e.g., John Durie, Government cracks the whip, The AUSTRALIAN FinANCIAL ReVIEw, Feb. 2, 2005, 56: 'All cartels are hard core and in this instance the new law should apply to as wide a group of offences as possible, including bid rigging, price setting and market sharing'.

${ }^{123}$ Note, however, that in the United Kingdom, the Memorandum of Understanding between the Office of Fair Trading and the Serious Fraud Office (who prosecute the offence) indicates that $a$ factor the Serious Fraud Office will consider when deciding whether to investigate will be whether the alleged fraud exceeds $£ 1$ million. It does, however, make clear that this is simply a 'signpost of seriousness ... rather than the main indicator of suitability' for investigation: MEMORANDUM OF UNDERSTANDING BETWEEN THE OFFICE OF FAIR TRADING AND THE DIRECTOR OF THE SERIOUS FRAUD OFFICE 5 (October 2003).

${ }^{124}$ Law Council of Australia, Submission to Working Party, supra note 99, at 7, $1[2.4$.

${ }^{125} I d$. at 8, I2.4.1. This conclusion is, however, reached on the belief that if that were the case then large companies could potentially face 'criminal sanctions for conduct which, if engaged in by smaller companies, even as members of the same cartel, would attract the far less serious civil penalties' which is not accurate; the proposed financial thresholds look to value of commerce affected rather than individual participants.

${ }^{126}$ Editorial, Punishment must fit Crime, The Australian FinANCIAL REVIEW, Feb. 2, 2005, 54.

127 Id. 
would be an increase in the number of persons driving within $20 \mathrm{~km}$ over the speed limit.

\section{Penalties}

The Government proposes that individuals found guilty of the cartel offence should be subjected to a maximum of five years imprisonment ${ }^{128}$ and a fine of up to $\$ 220,000$. For corporations a maximum fine of 'the greater of $\$ 10$ million or three times the value of the benefit from the cartel, or where the value cannot be determined, 10 per cent of annual turnover' would be available. For corporations this is higher than the existing maximum civil penalty of $\$ 10 \mathrm{~m}$, but it equates with the maximum civil penalty recommended by the Dawson Committee and which forms part of the current Amendment Bill. ${ }^{129}$ Presuming the bill passes through as expected, it will then be only the nature of the fine as criminal that distinguishes a corporation's penalty from that available under the civil regime.

The BCA has claimed the proposed fines for corporations are 'unrealistic' ${ }^{, 130}$ and unfair on certain companies. ${ }^{131}$ Along similar lines the Australian Chamber of Commerce and Industry has claimed there is no evidence suggesting existing penalties were insufficient, claiming 'the penalties are quite steep now'. ${ }^{132}$ There is, however, little to support these assertions. On the contrary, there is a wealth of evidence suggesting the current regime is inadequate, most notably the continuing prevalence of cartel conduct. ${ }^{133}$ In addition, given the reluctance of the courts in the past to impose the maximum fine available, it is likely that courts will continue consider factors such as the corporation's ability to pay and the consequences that might flow to staff, shareholders and customers if the company collapses, when imposing an appropriate remedy. Rather than providing 'steep' penalties, Australia is currently on the low end of the scale when it comes to penalties for cartel conduct, and, in those jurisdictions where higher penalties are available (in many cases higher than the Government's proposed maximum penalties) they have had the

\footnotetext{
${ }^{28}$ The Treasurer notes that by setting a penalty maximum, 'judges may use their discretion to determine the penalty in the particular circumstances before the court, taking into account a range of sentencing considerations, including whether there has been previous offending, the circumstances of the victim or victims, whether the person has cooperated and the deterrent effect': Treasurer, Criminal Penalties for Serious Cartel Behaviour, supra note 2.

129 'The Government considers financial disincentives for corporations who engage in cartel conduct should be at least as strong in the criminal regime as in the civil regime': Treasurer, Criminal Penalties for Serious Cartel Behaviour, supra note 2.

${ }^{130}$ See O'Loughlin, supra note 68 , at 4.

131 'Business Council of Australia general manager of government and regulatory affairs Steven Munchenberg said the prospect of being fined 10 per cent of annual turnover was unfair to companies with multiple subsidiaries, which may not have been party to the cartel action, but whose revenue would inflate the cost of the penalty': Speedy, supra note 63.

${ }^{132}$ Chief Executive Peter Hendy, quoted in Speedy, supra note 63

${ }^{133}$ See Editorial, Punishment must fit Crime, supra note 126, at 54. 'Business people ... cannot ... argue that the creation of criminal offences for serious cartel conduct is not warranted by its prevalence.' This is evidenced by the fact that the ACCC is currently investigating more than 20 cartels which, given the law detection rates of cartels, is a telling figure: see Kate Gauntlett, Cartels can bring jail terms and big fines, The West Australian, Feb. 3, 2005, Metro 10.
} 
benefit of enabling the imposition of very large fines in appropriate cases, but have not proved 'unrealistic' for cartel conduct generally. The simple solution for business worried about large fines is, of course, to refrain from engaging in the unlawful conduct. $^{134}$

For individuals the maximum financial penalty is lower than its civil counterpart in recognition of the fact that criminal conviction also attracts other adverse consequences, including 'strong social stigma' and disqualification from 'participation in certain activities. ${ }^{135}$ Nevertheless, a fine at least equal to the civil fine available for the same conduct, but absent the 'dishonest' element, would be more appropriate. It is notable that other jurisdictions have not, when imposing criminal sanctions, lowered the fine payable to below that of the civil standard. In the UK, for example, which only recently introduced criminal penalties for cartel conduct, an unlimited maximum fine is available for individuals in addition to a five year maximum prison term. In Ireland, in addition to prison terms, a fine of up to $€ 4 \mathrm{~m}$ or $10 \%$ of turnover is available. ${ }^{136}$ Similarly, in the United States, the maximum fine for individuals is now US\$1 million. ${ }^{137}$ Australia's proposed maximum criminal fine is strikingly modest by comparison.

The maximum term of imprisonment of five years is also on the low end of the scale when compared with fraud related offences in Australia that range from five to ten years, raising some issues of comparability. Nevertheless, the five years does fall within the existing international maximum range of two to ten years. The United States and Mexico ${ }^{138}$ sit at the top of the scale with up to ten years imprisonment, Canada, Ireland, Israel and UK all impose maximum jail terms of five years, France imposes a four year maximum ${ }^{139}$ and Japan imposes a three year maximum term. Consequently, while there are some issues of comparability with other crime, particularly other white collar crime, in Australia, by international standards the five year maximum term is middle-of-the-range.

The BCA has claimed that prison sentences for individuals constitute an overreaction by the Government. ${ }^{140}$ One of the expressed concerns has been that directors of large companies, unaware of what is happening, could be subjected to criminal

\footnotetext{
134 See, for example, Punishment to fit the cartel crime, THE AGE, Feb. 4, 2005, 14: 'In our view, reputable companies have nothing to fear from the reforms and Australians have much to gain from fair and open competition'.

${ }^{135}$ Treasurer, Criminal Penalties for Serious Cartel Behaviour, supra note 2. The criminalisation of cartel conduct will also mean that the Proceeds of Crime Act 2002 will apply where an offence is proved. ${ }^{136}$ Competition Act, 2002 (Ireland). See also Helen Kelly and Karen Gibbons, Ireland, in CARTEL REGULATION 2004: GETTING THE FINE DOWN IN 29 JURISDICTIONS WORLDWIDE 80-81 (2004).

${ }^{137}$ Recent increase: until the passing of the Antitrust Criminal Penalty Enhancement and Reform Act of 2004 the maximum fine payable by individuals was $\$ 350,000$ (but note this could be increased)

${ }^{138}$ Federal Law of Economic Competition (Mexico). See further León Ricardo Elizondo, Mexico, in CARTEL REGULATION 2004, supra note 136, at 100-105.

${ }_{139}$ See Didier Théophile and Nathalie Lobel, France, in CARTEL REGULATION 2004, supra note 136, at 62-68.

${ }^{140}$ Frank Cassidy, Chamber chief says cartel crackdown is overreaction, CANBERRA TIMES, Feb. 4, 2005,13 .
} 
fines or imprisonment. ${ }^{141}$ This concern is, of course, unjustified considering the requirement of individual dishonesty before a director could be exposed to a criminal conviction. ${ }^{142}$ These criminal penalties, for both companies and individuals, are appropriate given the extent of cartel activity that exists and the treatment of less damaging conduct, and are, for reasons outlined earlier, likely to provide a much more effective deterrent against the engaging in such conduct.

In addition to criminal fines and possible jail terms, the range of other remedies that exist under the TPA for business and individuals, 'such as the payment of compensation or injunctions or adverse publicity orders', as well as the proposed option to 'disqualify an individual implicated in a contravention from managing a corporation', will also be available for those convicted under the cartel offence. ${ }^{143}$

\section{E Excluding certain conduct}

Existing exclusions under the civil regime for certain forms of conduct, that might otherwise fall within the cartel offence, will be immune from criminal sanction. This is appropriate and still remains consistent with the OECD recommendation. There should be no practical difficulty in extending these exclusions to the cartel offence.

\section{F Managing civil and criminal penalties}

The Government has indicated that the same conduct prohibited by the new cartel offence, absent the dishonesty element, will also become a per se civil contravention of the TPA. This duplication of prohibitions requires some mechanism by which the ACCC can determine which contraventions will proceed through the civil system and which through the criminal. In rare cases where conduct has been engaged in but the element of dishonesty is absent, the civil system will need to be pursued. In other cases factors set out earlier, such as commerce affected and prior contraventions will guide the ACCC's decision of whether to pursue criminal prosecution over civil action. Other issues might also influence the ACCC's decision, such as whether they are likely to be able to prove a contravention 'beyond reasonable doubt' as opposed to on the balance of probabilities for civil actions.

The Government proposes that the ACCC release guidelines, developed in consultation with the DPP, which set out factors that will be 'relevant to determining whether to pursue a criminal or civil investigation. ${ }^{144}$ In particular, as discussed earlier, they wish to ensure that criminal sanctions are only pursued 'where they can

\footnotetext{
${ }^{141}$ See, for example, ACT Chamber of Commerce chief executive, Chris Peters, quoted in Cassidy, supra note 140 , at 13 .

${ }^{142}$ Note Graeme Samuel has indicated that 'senior managers unaware of illegal activities could not be prosecuted and sent to jail, because legal processes demanded evidence of complicity': Cassidy, supra note 140 , at 13 .

${ }^{143}$ Treasurer, Criminal Penalties for Serious Cartel Behaviour, supra note 2.

144 Id.
} 
be clearly justified' ${ }^{145}$ and have indicated that the ACCC should not 'ordinarily refer relatively minor matters to the DPP for criminal prosecution.'

In terms of what would justify criminal sanction, the Government has, as outlined earlier, focussed on whether a significant amount of commerce is affected. In addition to those 'size' factors the ACCC will be required to consider, before referring a matter to the DPP, whether 'one or more of the alleged participants has previously been found by a court to have participated in, or has admitted to participating in, cartel conduct, either criminal or civil.' Similarly, the DPP, in making its 'independent determination as to whether to prosecute a particular matter' must consider whether any of the alleged members of the cartel have previously been found by a criminal or civil court, or admitted, to have engaged in cartel behaviour' in addition to the evidence available and the Prosecution Policy of the Commonwealth (the Prosecution Policy). ${ }^{146}$ It is suggested that neither prior conduct nor commerce affected are appropriate requirements for considering whether alleged contraventions of the cartel offence are pursued. The issue of commerce affected was addressed earlier. In relation to prior contraventions, given the historic difficulty in detecting and proving cartel conduct, particularly prior to the ACCC's leniency policy, proof of prior contravention means very little; the current offenders might simply have been involved in successful - undetected - cartels in the past. Even if they have not, the deterrent effect for first time offenders is diminished if they believe that a clean track record - however accurate - is likely to save them from criminal prosecution. These are considerations more appropriately left to sentencing. Provided the ACCC has the evidence necessary to justify criminal proceedings, requiring a higher burden of proof, and whistleblower protection does not apply, criminal sanctions should be pursued in all cases.

The benefits of criminalising cartel conduct will only be realised if they are actively pursued by the ACCC and the DPP. In cases where the ACCC believes a cartel offence has taken place and investigation reveals sufficient evidence - or the likelihood of obtaining sufficient evidence - for purposes of criminal prosecution, ${ }^{147}$ they must refer the matter to the DPP who must then prosecute. The regime will prove ineffective as a deterrent if individuals believe that in the majority of cases the ACCC will simply pursue civil remedies. Currently, for example, only the United States and Canada have successfully pursued jail terms for cartel offences, despite the fact that this potential remedy exists in a number of other jurisdictions. ${ }^{148}$

Another key difficulty will be dealing with the concurrent pursuit of remedies under both the civil and criminal regime. This is likely to occur frequently, as any conduct falling within the cartel offence will also automatically contravene the civil

\footnotetext{
145 Id.

146 Id.

${ }^{147}$ It is presumed the higher threshold of 'guilty beyond all reasonable doubt' will be imposed for the cartel offence rather than the existing civil, balance of probabilities test.

${ }^{148}$ See OECD, REPORT ON THE NATURE AND IMPACT OF HARD CORE CARTELS, supra note 3, at 2 and Sheridan Scott, Cartel Enforcement: International and Canadian Developments, Speech to the Fordham Corporate Law Institute, Conference on International Antitrust Law and Policy 14 (Oct. 7, 2004).
} 
prohibition which the Government has indicated will be consistent with the criminal offence. In this respect the Law Council, in its submission to the Working Party, suggested that Recommendation 11.2 ALRC Report Principled Regulation should be followed, ${ }^{149}$ which provides

Recommendation 11-2. Legislation that provides for exposure to parallel criminal proceedings and civil penalty proceedings for the same or substantially the same conduct should also provide that:

(a) civil penalty proceedings against a person must be stayed if criminal proceedings are commenced, or have already been commenced, against that person for a criminal offence constituted by conduct that is the same or substantially the same as the conduct alleged to constitute the civil penalty contravention;

(b) no, or no further, civil penalty proceedings may be taken against a person if that person has been convicted of a criminal offence constituted by conduct that is the same or substantially the same as the conduct alleged to constitute the civil penalty contravention; and

(c) if the person is not convicted of that criminal offence, the civil penalty proceedings may be resumed.

This Recommendation is not intended restrict the ability of a regulator to seek compensation orders, disqualification orders or preservation orders. ${ }^{150}$

This is a logical and sensible recommendation which it appears the Government is willing to follow. The Government has appropriately stated that:

existence of parallel civil and criminal provisions for potentially the same conduct could give rise to issues concerning the order in which matters are litigated and the appeals process. Therefore, statutory bars will be incorporated in the Trade Practices Act to provide appropriate protection, for example, to stay civil proceedings until criminal proceedings are completed, after which time, if the defendant is convicted, the civil proceedings would be terminated.

Concurrent civil and criminal prohibition also raises the problem of ensuring that any evidence gathered is done so in accordance with criminal standards where criminal prosecution is likely to be pursued. In this respect the Government has indicated it is desirable for the ACCC to 'determine early in an investigation whether it will proceed civilly or criminally' because of the varying evidentiary requirements for civil and criminal investigation and prosecution. However, this

\footnotetext{
${ }^{149}$ Law Council of Australia, Submission to Working Party, supra note 99, at 14.

${ }^{150}$ Australian LaW ReForm Commission, PrinCiPLED REgulation: Civil AND AdMinistrative PenAlties in Australian Federal Regulation, (Commonwealth of Australia, Oct. 2002)
} 
may prove difficult in practice, ${ }^{151}$ as it is likely to be only after significant investigation that the ACCC can make an assessment of whether, in fact, there has been a breach and, if so, whether they can acquire the evidence necessary for successful criminal prosecution. In this respect the ACCC and DPP may be guided in the development of their MOU, by the UK's recent Memorandum of Understanding between the Office of Fair Trading (OFT) and the Director of the Serious Fraud Office $^{152}$ and the OFT's publication outlining powers for investigating criminal cartels, which sets out when criminal investigative powers should be used and how they differ from evidence gathering in purely civil cases. ${ }^{153}$ Provided these are clearly set out through a combination of legislation, where appropriate, and guidelines for the DPP and ACCC to follow, this should not prove too problematic in practice.

\section{G The ACCC and the DPP}

The Government has indicated that ACCC will have the role of investigating possible breaches of the cartel offence and the DPP will have the role of prosecuting cases. The introduction of a new enforcement body to the competition law regime in Australia necessitates an appropriate delineation of responsibilities between the ACCC and DPP. This will be set out in the MOU between these bodies, which will also 'establish standards of cooperation between agencies in the investigation and litigation process', outline channels of communication and 'specify processes for the consideration of immunity applications'. ${ }^{154}$ Little detail of this aspect of the MOU has been released.

\section{H Whistleblower protection - leniency}

Cartels are, by their nature, highly secretive ventures. As a result, it has been observed that the enforcement costs in order to achieve a high level of detection in relation to cartel conduct are extremely high - and perhaps prohibitive. ${ }^{155}$ If increased detection measures are not put in place, and the perception that only a remote possibility that breaches of Part IV will be detected is allowed to flourish,

\footnotetext{
${ }^{151}$ It has been suggested that the ACCC will be required to decide on day one whether to opt for criminal or civil penalties: Fred Brenchley, Cartels compelled to come clean, THE AUSTRALIAN FINANCIAL REVIEW, Feb. 2, 2005, 4. However, a time frame has not yet been made clear by the government.

${ }^{152}$ MEMORANDUM OF UNDERSTANDING, supra note 123, at 5.

153 OFFICE OF FAIR TRADING (UK), POWERS FOR INVESTIGATING CRIMINAL CARTELS (Jan. 2004).

154 Treasurer, Criminal Penalties for Serious Cartel Behaviour, supra note 2.

155 Wils, supra note 51, at 22. See also James Griffin,

... cartels are secret conspiracies. Cartel members simply do not broadcast to the world that they have met and agreed to limit output and raise prices. On the contrary, cartel members go to great lengths to avoid detection of their fraudulent conduct. More often that not, even the customers of the cartel members are unaware that they are being victimized. These characteristics of a cartel make it one of the most difficult white collar crimes to investigate and prosecute.

quoted in Law Council of Australia, Submission to Working Party, supra note 99, at 16.
} 
then any other measures that are employed to encourage compliance with Part IV are likely to be futile.

The Law Council of Australia, in its submission to the Working Party therefore, sensibly, recommended that the amnesty currently available under the civil regime be available under the criminal regime, ${ }^{156}$ provided this could be done without the DPP retaining its approach to amnesty "which retains significant prosecutorial discretion. ${ }^{157}$

An effective leniency policy is increasingly being recognised as a crucial element in the deterrence of cartels as well as penalties for individuals. ${ }^{158}$ This is because such policies increase the risk of detection of cartels and will, therefore, be an important factor for individuals to contemplate when considering whether to engage in such conduct. In relation to deterrence generally, that it is clear that the greater the perceived likelihood of detection, the more likely it is that prospective offenders will be dissuaded from offending. ${ }^{159}$ In this respect, the OECD has reported that

[s]trong sanctions against enterprises and individuals increase the effectiveness of leniency programs in uncovering cartels and provide incentives to cartel participants to co-operate with a cartel investigation., 160

This has proved to be the case under the existing policy, with the ACCC believes its has proved 'a very effective incentive for exposing cartels' ${ }^{161}$ This formal leniency policy for cartel conduct offers immunity from ACCC instigated proceedings ${ }^{162}$ where the applicant was the 'first to disclose the existence of a cartel of which the ACCC was previously unaware; or immunity from pecuniary penalty, where the leniency applicant is the first to make an application for leniency in relation to a cartel of which the ACCC was aware, but in relation to which the ACCC had insufficient evidence to commence court proceedings. ${ }^{163}$

A recent successful example of the application of the ACCC's leniency policy arose in the context of a price-fixing arrangement between Metro Brick and Midland Brick relating to clay bricks in Western Australia. Following an allegation of price fixing by the ACCC in 2001 'Boral Ltd, of which Midland Brick is a wholly-owned

\footnotetext{
${ }^{156}$ Law Council of Australia, Submission to Working Party, supra note 99, at 20.

${ }^{157} I d$. at 20.

158 See Id. at 15 and OECD, Fighting HARD CORE CARTELS, supra note 73, AT 82.

159 This was acknowledged by the Dawson Committee who noted that 'certainty of detection is a better deterrent than severity of punishment for most criminal offences': Dawson Report, supra note 31, at 158. See also Treasurer, Criminal Penalties for Serious Cartel Behaviour, supra note 2: 'international experience suggests that immunity programmes have been highly successful in combating cartel activity. Therefore, an immunity policy enhances the deterrent effect of criminal penalties.'

${ }^{160}$ OECD, REPORT ON THE NATURE AND IMPACT OF HARD CORE CARTELS, supra note 3, at 2.

161 Press Release, ACCC, ACCC further steps up fight against Cartels (Nov. 24, 2004).

162 Note that the policy provides no protection from third party claims. However, these are rare and, in any event, third parties are not able to claim pecuniary penalties.

163 McNeill, supra note 11. This is subject to other conditions set out in the policy: ACCC, ACCC LENIENCY POLICY, supra note 14.
} 
subsidiary, approached the ACCC and voluntarily disclosed the potential contraventions. ${ }^{, 164}$ Subsequently the court imposed a penalty of $\$ 1$ million on Metro Brick and a penalty of $\$ 25,000$, a senior manager of Metro Brick, for their involvement in the price-fixing. Midland Brick received an injunction restraining them from engaging in similar conduct for five years and was ordered to pay costs to the ACCC. However, both Midland Brick and the senior manager involved avoided pecuniary penalty. ${ }^{165}$ More recently, Amcor sought leniency from the ACCC in exchange for information about the cartel conduct in the corrugated box business and full cooperation with ACCC investigations and proceedings. This conduct is currently being investigated. $^{166}$

It is important that the Government incorporate a leniency policy into the criminal cartel regime and it has indicated that it will do so in the form of a whistleblower protection policy. Guidelines are to be formulated to determine when immunity will be provided to whisleblowers by the DPP.

An immunity policy is generally accepted to be more effective when immunity can be offered in the early stages of an investigation. However, in Australia, the discretion to provide immunity from criminal proceedings is currently exercised by the DPP at the conclusion of an investigation. The exercise of this discretion is guided by the Prosecution Policy.

It is proposed that the Prosecution Policy be amended to enable immunity to be granted at an early stage in an investigation. This would be on the recommendation of the ACCC, and where the applicant meets certain conditions. ${ }^{167}$

To maximize incentives for potential whistleblowers, the Government recommended that:

the first party to approach authorities before they are aware of the cartel should receive the most favourable treatment. If parties delay until there is sufficient evidence to institute proceedings or they are not the first to approach the authorities, they should not receive immunity.

The proposed criteria for the grant of immunity will be similar to those existing under the ACCC's current leniency policy. In particular, a whistleblower will receive immunity only if:

\footnotetext{
${ }^{164}$ Press Release, ACCC, \$1 million penalty for brick price fix (June 9, 2004).

165 Id.

166 Amcor applied for leniency on 22 November 2004 after becoming aware of cartel conduct by officers and employees on 19 November: AMCOR LiMITED, HALF-YEAR REPORT, 12-13 (Dec. 31 2004). The revelations of cartel conduct by Amcor have led to resignations of its Chief Executive Officer, Russell Jones, and two other senior managers (see ACCC heavies packaging giant Amcor (Dec. 8, 2004) available at ABC online <http://www.abc.net.au/am/content/2004/s1260358.htm>. See further Kate Askew, Former Amcor executives escape, THE AGE, Dec. 18, 2004 (online) at

<http://www.theage.com.au/news/Business/Former-Amcor-executivesescape/2004/12/17/1102787275472.html>.

${ }^{167}$ Treasurer, Criminal Penalties for Serious Cartel Behaviour, supra note 2.
} 
- the ACCC was not already aware of the conduct;

- the party was the first to come forward (subsequent applicants for immunity should be dealt with under the existing provisions in the Prosecution Policy);

- the party was not a clear individual leader in the cartel;

- the party had not coerced anyone to join the cartel; and

- the party fully cooperates with the ACCC and attends court to give evidence, as required. ${ }^{168}$

Provided the DPP's Prosecution Policy is amended as suggested by the Government and the new whistleblower protection policy does not weaken the ACCC's existing and successful leniency policy, this is an essential component of an effective cartel enforcement regime and should assist in both detection and effective prosecution of the new cartel offence as well as adding another layer of deterrent for those contemplating cartel conduct.

\section{RECOMMENDATIONS FOR IMPLEMENTATION}

It is as yet unclear how the Government's proposals will be incorporated into the TPA. As indicated above, the preferred method would be to incorporate them in such a way as to cause minimum disruption to existing provisions for which there is substantial jurisprudence. This way the authorities, parties and courts could draw, as much as possible, on existing definitions that would help inform the application of the cartel offence and the amended civil per se offence.

The most appropriate way to do this would be through the modification of section 45 of the TPA, which currently encompasses all forms of cartel conduct whether directly or with the aid of associated provisions which deem certain forms of conduct, like price fixing, to substantially lessen competition. In particular, the existing s 45A should be repealed and replaced with a new s 45A deeming all forms of cartel conduct outlined in the Government's proposal to substantially lessen competition for the purposes of $\mathrm{s} 45$; that is, making them all subject to per se civil penalty.

This is relatively easy for price-fixing which has an established definition in the TPA; the other forms of hard core conduct are caught either via the price fixing provision or more generally by s 45 only if they substantially lessen competition and have no existing definition within the TPA. ${ }^{169}$ It is suggested the following definitions would be appropriate.

\footnotetext{
${ }^{168} I d$.

${ }^{169}$ Output restrictions and bid rigging are potentially caught as forms of price fixing by s $45 \mathrm{~A}$; sharing or dividing markets on the other hand is likely to be caught by s 45 only if it can be demonstrated the conduct substantially lessened competition.
} 


\section{Section 45A: Cartelisation}

(1) Price Fixing

A provision of contract, arrangement or understanding, or of a proposed contract, arrangement or understanding, shall be deemed for the purposes of section 45 to have the purpose, effect, or likely effect of substantially lessening competition if the provision has the purpose, or has or is likely to have the effect of

(a) fixing, controlling or maintaining, or

(b) providing for the fixing, controlling or maintaining of the price for, or a discount, allowance, rebate or credit in relation to, goods or services supplied or acquired or to be supplied or acquired by

(c) the parties to the contract, arrangement or understanding or

(d) the proposed parties to the proposed contract, arrangement or understanding, or

(e) by any of them, or

(f) by any bodies corporate that are related to any of them in competition with each other.

(2) Output Restrictions

A provision of contract, arrangement or understanding, or of a proposed contract, arrangement or understanding, shall be deemed for the purposes of section 45 to have the purpose, effect, or likely effect of substantially lessening competition if the provision has the purpose, or has or is likely to have the effect of restricting the output of goods or services supplied or to be supplied by

(a) the parties to the contract, arrangement or understanding or

(b) the proposed parties to the proposed contract, arrangement or understanding, or

(c) by any of them, or

(d) by any bodies corporate that are related to any of them in competition with each other.

(3) Bid Rigging

A provision of contract, arrangement or understanding, or of a proposed contract, arrangement or understanding, between two or more persons, shall be deemed for the purposes of section 45 to have the purpose, effect, or likely effect of substantially lessening competition if, in response to a call for tenders,

(a) one or more parties agree to not submit a bid; or

(b) two or more parties submit bids arrived at by agreement or arrangement ${ }^{170}$

\footnotetext{
${ }^{170}$ Note that this is similar to the Canadian prohibition on bid rigging: Competition Act, $\S 47$ (Canada).
} 
and the person who called for the tenders was not made aware of any agreement or arrangement, at or before the time at which bids were submitted.

(4) Market Sharing

A provision of contract, arrangement or understanding, or of a proposed contract, arrangement or understanding, between two or more persons, two or more of whom are in competition with each other, shall be deemed for the purposes of section 45 to have the purpose, effect, or likely effect of substantially lessening competition if it has the purpose or effect of sharing markets between two or more of the cartel members, whether by customer, geographic or any other criteria.

Finally, the parallel criminal offence of cartel conduct could be incorporated as s 45AA of the TPA, providing that all forms of conduct prescribed in $\mathrm{s} 45 \mathrm{~A}$, which have been engaged in dishonestly, are prohibited. For example:

\section{Section 45AA: Cartel Offence}

(1) A corporation which, dishonestly, engages in any of the forms of conduct set out in s 45A, is guilty of an offence punishable on conviction by a fine not exceeding, for each act or omission, the greatest of the following:

(a) $\$ 10,000,000$;

(b) if the Court can determine the value of the benefit that the body corporate, and any body corporate related to the body corporate, have obtained directly or indirectly and that is reasonably attributable to the act or omission -3 times the value of that benefit;

(c) if the Court cannot determine the value of that benefit $-10 \%$ of the annual turnover of the body corporate during the period of 12 months ending at the end of the month in which the act or omission occurred. ${ }^{171}$

(2) An individual who, dishonestly, engages in any of the forms of conduct set out in $\mathrm{s} 45 \mathrm{~A}$, is guilty of an offence punishable on conviction by a fine not exceeding $\$ 220,000$ (or such amount as prescribed by regulation) or imprisonment for a term not exceeding five year, or both.

This approach would be consistent with how the TPA deals with overlapping civil and criminal provisions in relation to consumer protection and would cause less disruption to the existing regime, thus reducing the level of uncertainty associated with new laws.

\footnotetext{
${ }^{171}$ Note that this wording essentially mirrors that in the Amendment Bill relating to civil pecuniary penalties: Trade Practices Legislation Amendment Bill (No. 1) 2005, Schedule 9 §4. It would also be necessary to ensure that the proposed new s 76(5), which defines 'annual turnover' for the purposes of the new pecuniary penalty regime, was re-worded to ensure it also applied to the new s 45AA: Trade Practices Legislation Amendment Bill (No. 1) 2005, Schedule 9 §7.
} 
Naturally, there would need to be some associated changes. Part VI of the TPA dealing with remedies would then need to accommodate the new provisions, including providing some different criteria for investigating potential breaches of the cartel offence. Anti-overlap provisions would also need to be modified. Currently, for example, entering into an exclusionary provisions takes precedence over other $\mathrm{s}$ 45 contraventions where there is overlap. This would need to be altered to ensure that this did not occur in all cases and could be done simply by providing that $\mathrm{s} 45 \mathrm{~A}$ and 45AA take precedence over s 45(2)(a) and all other provisions of Part IV.

\section{WHERE TO FROM HERE?}

In order to ensure the changes apply to individuals as well as corporations, changes need to be made to the text of the Competition Code. ${ }^{172}$ This change requires consultation with the States and Territories over a period of at least three months. ${ }^{173}$ At the expiry of three months the Commonwealth may 'call a vote on each of the proposed amendments by sending written notice' to each participating jurisdiction. ${ }^{174}$ The Commonwealth has two votes and a casting vote and each other participating jurisdiction has one vote. ${ }^{175}$ If a jurisdiction fails to vote within 35 days of the Commonwealth's notice it will be 'taken to have voted in favour of the amendment'. ${ }^{176}$ Despite Labor governments in the States, it is likely that the Commonwealth will obtain the necessary votes given Labor has indicated that it welcomes the introduction of criminal sanctions. At this stage it is, therefore, anticipated that the Trade Practices Amendment (Cartel Conduct) Bill 2005 will be introduced into Parliament sometime in June or August and come into force by the end of the year. ${ }^{177}$

It will also be important for the MOU and ACCC guidelines, including guidelines on the whisteblower policy to be developed between now and the time at which any amendments are likely to take effect. This will provide some increased certainty for business contemplating engaging in such conduct or in confessing to having engaged in that conduct.

\footnotetext{
172 The Competition Code comprises a schedule version of Part IV of the Trade Practices Act, 1974 (Cth) designed to extend the scope of that Part to areas outside the federal Government's constitutional powers.

${ }^{173}$ 'The Commonwealth will consult with fully-participating jurisdictions before it puts forward for parliamentary consideration any modification to Part IV of the Trade Practices Act of to the Competition Code text': Conduct Code Agreement, \$6(1). Section 7 further requires that consultation be by written notice and allow parties a period of three months to respond.

${ }^{174}$ Conduct Code Agreement, §6(3).

175 Conduct Code Agreement, $\$ 6(4)$.

176 Conduct Code Agreement, §6(5).

177 Parliament is not sitting in July. See also Rowland, supra note 40. Note, while the government has not publicly indicated a timeframe this appears a reasonable estimate. See supra note 40.
} 


\section{CONCLUding Remarks}

The current civil penalty regime for hard core cartel conduct has fallen well behind international best practice. It provides insufficient deterrence against cartel conduct and raises issues of fairness when compared to other similar and often less damaging forms of conduct that attract criminal penalties.

The introduction of higher civil penalties, together with a new criminal penalty regime for cartel conduct, including the prospect of jail time for offenders, should go some way to addressing these issues; in particular, it is likely to prove a more effective deterrent against cartel conduct which is estimated to cost the international economy billions of dollars each year.

It is hoped these changes will be implemented quickly and will be implemented in such a way as to cause minimum disruption to existing law. It is further hoped that the Government revises its criteria for determining if and when it will pursue criminal proceedings, in particular, by removing reference to cartel or business size as a criteria. All forms of conduct proposed to be criminalised are almost universally considered 'hard core' and should prima facie be treated in the same way be the authorities, less arguments of fairness and equality arise. 